\title{
Konferenssiraportti on helposti harvojen helmien hautausmaa
}

\section{Anja Heikkinen (ed.) 1995. Vocational Education and Culture - European Prospects from Theory and Practice. Tampereen yliopiston opettajankoulutuslaitos. 259 sivua.}

Julkaisu on toimittajan sanoja lainatakseni "yksi linkki lisää tutkimusverkoston yhteistoiminnan ketjuun". Kyseessä on kuuden eurooppalaisen yliopiston yhteistyö, joka sisältää työpajoja, kokouksia, vierailuja, yhteisjulkaisuja ja yhteisiä tutkimushankkeita. Kokoelman artikkelit perustuvat Hämeenlinnassa kesäkuussa 1995 pidettyyn verkoston seminaariin.

Toimitetun teoksen arvioinnissa - tapahtuupa se sitten julkaisemista harkittaessa tai valmiin julkaisun tasoa arvioitaessa - keskeisellä sijalla on tavallisesti pohtia teoksen yhtenäisyyttä. jopa siinä määrin, että teoksen varsinainen sisältö, artikkelien anti, saattaa jäädä toissijaiseksi. Yhtenäisyys ei ole tämän kirjan vahva puoli. Teoksella on tosin pari yhteistä nimittäjää: jo mainittu seminaari ja yhteinen teema; ammattikasvatus. jälkimmäinen kuitenkin suhteellisen väljästi määriteltynä. Monien konferenssiraporttien tapaan, yhdistävät säikeet jäävät näin suhteellisen ohuiksi.

Itseäni ei kuitenkaan suuresti kiusaa teoksen epäyhtenäisyys. Yhdessä suhteessa yhtenäisyyden vaatimus on kuitenkin perusteltu: koherentille teokselle on helpompaa löytää luonteva kohdejoukko ts. ostajakunta kuin teemoiltaan ja tyyliltään kovin epäyhtenäiselle kirjalle. Tämä onkin teoksen ongelma: selkeää kohdejoukkoa ei ole, ellei sellaiseksi sitten määritellä "kaikkia ammattikasvatuksesta kiinnostuneita". Lisämääreinä tulisi vielä mainita vaatimus potentiaalisen lukijan englannin ja saksan kielen taidosta. Artikkelit kun on julkaistu jommalla kummalla näistä kielistä.

Teoksen artikkelien teemat liikkuvat kovin erilaisilla poluilla ammattikasvatuksen väljästi määritellyssä maastossa. Toimittaja on jakanut maaston kolmeen alueeseen: (1) hallinto ja politiikka, (2) työelämä sekä (3) kouluttajat ja opiskelijat. Nämä alueet vastaavat seminaarin rakennetta. Sisällysluetteloa katsoessa hämmensi aluksi se, että jotkut artikkelien otsikoista oli sisennetty, joitain taas ei. No, selvisihän se johdannossa: sisennetyt olivat työryhmäistuntojen esitelmiä ja sisentämättömät yleisistuntojen. Tämä on ehkä yleinenkin käytäntö, mutta mielestäni tarpeetonta etukäteisarviointia lukijan puolesta: hyvä artikkeli kyllä saa sille kuuluvan arvon, olipa se sitten yleis- tai työryhmäesitelmä. Sama pätee huonoon - luonnollisesti.

Yhteensä teoksessa on 17 artikkelia. Näiden kaikkien esittely tässä ei tietenkään ole mahdollista. Haluan kuitenkin nostaa esiin muutamia, jotka omalta kannaltani olivat erityisen kiinnostavia.

\section{Valtion kehitysaste ja koulutus}

Andy Green analysoi vertailevassa artikkelissaan 'Education and the Developmental State in Europe and Asia' koulutuksen roolia valtion muotoutumisessa tietyntyyppisissä yhteiskunnan kehitysvaiheissa. Valtion muotoutumisella (state formation) hän tarkoittaa historiallista prosessia, jossa kansallisvaltiot muotoutuvat tai uudelleenmuotoutuvat.

Tarkastellessaan kansallisen koulutusjärjestelmän syntyä 1800luvulla, Green toteaa että Englanti, toisin kuin monet muut myöhemmin teollistuneet maat, vitkasteli julkisen koulutusjärjestelmän perustamisessa. Esimerkiksi kansallinen toisen asteen koulutus perustettiin lähes sata

vuotta sen jälkeen kun Napoleon oli aloittanut valtion lyseot Ranskassa. Green kyseenalaistaakin perinteiset koulutuksen muutosta käsittelevät teoriat, jotka kytkevät koulutusjärjestelmän kehityksen teollistumiseen ja kaupungistumiseen. Hän katsoo, että teoriat eivät pysty selittämään sitä, että kansalliset koulutusjärjestelmät syntyivät esimerkiksi Preussissa ja Ranskassa pääasiassa esiteollisessa maatalousyhteiskunnassa, kun taas varhain teollistuneessa Britanniassa kehitys oli suhteellisen hidasta. Tämän asian ymmärtämiseksi hän käyttää valtion muotoutumisen teoriaa. Green katsoo, että taloudellisilla pyrkimyksillä oli kyllä sijansa koulutusjärjestelmän rakentamisessa valtion muotoutumisen prosessissa. Niiden ohella erilaiset sisäiset ja ulkoiset konfliktit olivat kuitenkin usein jopa tärkeämpi peruste kansallisten koulutusjärjestelmien, ja tätä kautta kansallisen yhtenäisyyden, rakentamisessa. 


\section{Koulutus ideologian rakennuspuuna}

Toisen kiinnostavan näkökulman koulutukseen esittää Ronald G. Sultana artikkelissaan 'Vocational Schools and the Transition to Socialism in Malta'. Suomessa ammatillista koulutusta on tarkasteltu pääasiassa työmarkkinoiden sekä työtehtävien kannalta kiinnittämättä paljoakaan huomiota esimerkiksi koulutuksen tuottamaan identiteettiin ja koulutukseen liittyviin ideologisiin kysymyksiin. Artikkelissaan Sultana nostaa esille näistä jälkimmäisen. Hän toteaa, että sosialismiin siirryttäessä monissa maissa on taloudellisten tavoitteiden lisäksi sisällytetty ammatilliseen koulutukseen myös ideologisia pyrkimyksiä: tehdä työntekijät tietoisiksi työprosessista, nostaa ruumiillisen työn arvostusta, yhdistää käden ja mielen toiminta, edistää sosiaalista sekoittumista sekä tasa-arvoa. Hänen esimerkkinsä on Malta, jossa sosialistinen hallitus perusti vuonna 1972 ammatillisen koulutuksen järjestelmän, johon alusta saakka liitettiin mainittuja ideologisia tavoitteita. Näille ideologisille pyrkimyksille oli haettu pohjaa Marxista ja Deweystä samoin kuin neuvostojärjestelmän polyteknisen koulutuksen ideoistakin.

Sultanan mukaan tavoitteissa kuitenkin epäonnistuttiin. Erillisistä ammatillisista kouluista muodostui akateemista väylää huonompi koulutusväylä, johon hakeutuivat erityisesti työväenluokkaiset oppilaat. Esimerkiksi kommunistinen puolue oli toivonut ammatillisen koulutuksen tuottavan "orgaanisia intellektuelleja", jotka olisivat mukana tuotannossa, mutta samalla kykenisivät nostamaan luokkansa kulttuurista tietoisuutta. Mitään tällaista ammatillinen koulutus ei kuitenkaan saanut aikaan. Pyrkimys pään ja käden työn yhdistämisestäkin epäonnistui: jako akateemiseen ja ammatilliseen koulutusväylään vain kovensi jakoa niihin, joilla on "hyvä pää" ja niihin, jotka ovat "hyviä tekemään".

\section{Ammattikorkea koulujen rooli}

Micbael Young ja Ken Spours käsittelevät artikkelissaan 'A New Vocationalism? Reflections on the Finnish Polytechnics' kahta suomalaista ammattikorkeakoulu kokeilua; Pohjois-Karjalan ammattikorkeakoulua Joensuussa ja Kemi-Tornion ammattikorkeakoulua. Kirjoittajat katsovat, että ammattikorkeakoulun tulisi tarjota uusi visio korkeakoulutuksesta, joka poikkeaa sekä yleissivistävän (yliopistot) että ammatillisen koulutuksen traditioista. Vain tällä tavalla ne voivat omilla ansioillaan houkutella opiskelijoita sekä ammatillisista oppilaitoksista että lukioista ja välttää jäämistä yliopistopaikkaa vaille jääneiden vaihtoehdoksi.

Kirjoittavat esittävät ylevin sanakääntein seitsemän kohtaisen määritelmän tulevaisuuden ammattilaisesta sekä luettelon niistä ominaisuuksista, jotka häntä luonnehtivat. Suhteellisen lyhyen, mainittuihin oppilaitoksiin kohdistuneen tutustumiskäyntinsä pohjalta Young ja Spours ovat tunnistaneet ammattikorkeakouluja koskevia ristiriitoja ja ongelmia. Yhtenä näistä voisi mainita ristiriidan opiskelijoiden melko traditionaalisen ammatillista erikoistumista korostavan käsityksen ja enemmän laaja-alaisuutta ja innovatiivisuutta painottavan tulevaisuuden ammattilaisen ideaalin välillä. Opiskelijat arvostavat perusammattitaitoja, jotka antavat heille vaikutelman palkkatyöhön valmistautumisesta. Sen sijaan modernien työpaikkojen intellektuaalisemmat vaatimukset eivät heidän puheessaan tule esiin.

\section{Koulutus ja elämänkerta}

Ari Antikainen käsittelee artikkelissaan 'Life, Leaming and Empowerment' suomalaisten merkittäviä oppimiskokemuksia elämänkerrallisesta näkökulmasta. Tapausesimerkkejä artikkelissa on kaksi; jo aiemmistakin tutkijaryhmän esityksistä mieleenjäänyt 'moderni' Anna 66 sekä 'postmoderni' Taru 20. Kirjoittaja käyttää käsitettä empoverment kuvaamaan elämänkertomuksissa esiintulleita asioita: henkilön maailmankuvan laajeneminen tai kulttuurinen ymmärrys, henkilön 'äänen' vahvistuminen, joka tarkoittanee jonkinlaista henkilön oman sananvallan kasvua, sekä sosiaalisten identiteettien tai roolien alueen laajeneminen.

Kirjoittajan havainnon mukaan koulutus on Annan kertomuksessa instrumentaalista, ei kuitenkaan tiukan ammatillista. Tarun kertomuksessa peruskoulu näyttäytyy instrumentaalisena. Sen sijaan hänen hankkimansa ammatillinen koulutus, paitsi että sekin on tietysti instrumentti tulevia suunnitelmia silmälläpitäen, sisältää hänelle "todellista sisäistä ja sosiaalista merkitystä". Tulkitsisin niin, että kummassakin tapauksessa ammatillisten taitojen oppiminen merkitsee henkilölle mielekästä itsensä kehittämistä eikä ainoastaan jotain ulkoista pakkoa tai elämän välttämättömyyttä.

Antikaisen artikkeli on antoisaa luettavaa ja tarjoaa myös tutkimuksen tekemisen kannalta ainakin kaksi opetusta. Ensinnäkin kannattaa, Antikaisen tutkijaryhmän tapaan, etsiä uusia näkökulmia tutkimuskohteeseensa. Kasvatussosiologisen tutkimuksen perinteiset näkökulmat näyttävät tuottavan lähinnä perinteisiä tutkimustuloksia. Sen sijaan uusi näkökulmaa saattaa - ja tässä tapauksessa se myös niin tekee -avata Myös uusia ulottuvuuksia. Toisekseen kasvatuksen alueella sosiologian ja oppimisen tutkimuksen näkökulmien yhdistäminen tulosten tulkinnassa avartaa kuvaamme koulutuksesta ja oppimisesta verrattuna tilanteeseen että pysytään tiukasti omassa, vanhassa ja tutussa paradigmassa. 
Suomalaiselle lukijalle Antikaisen artikkeli on kirjan parasta antia, vaikka monille asiat lienevätkin tuttuja jo hänen yhdessä muiden tutkimusryhmän jäsenten kanssa aiemmin kirjoittamista artikkeleista.

Aiheiltaan, tasoltaan ja tyyliltäänkin kirjavaa teosta lukiessa on tullut mieleen kysymys, tuleeko tästäkin konferenssiraportista muutamien ansiokkaiden artikkelien "hautausmaa". Vähäinen levikki on tämän tyyppisen laitossarjassa julkaistun kirjan ongelma. Painosmäärät samoin kuin markkinointiponnistelut (oikeampi sanonta olisi ehkä tiedotus) jäävät usein vähäisiksi. Olipa niin tai näin, kirjan kokoaminen verkoston jäsenlaitosten ja muiden kiinnostuneiden käyttöön oli varmasti perusteltua. Teos ei varmaankaan ole enempää kuin osiensa summa, mutta toisaalta osien erotuskaan ei mene miinukselle.

Risto Honkonen 